九州大学学術情報リポジトリ

Kyushu University Institutional Repository

The Birth of Kūkai as a Literary Figure : A Translation and Analysis of Shinzei's Preface to the Henjō Hokki Shōryōshū

Matsuda, Wi lliam

Kyushu University : Visiting Associate Professor

https://doi.org/10.5109/1654568

出版情報: Journal of Asian Humanities at Kyushu University. 1, pp.29-37, 2016-03. Kyushu University, School of Letters, Graduate School of Humanities, Faculty of Humanities バージョン:

権利関係 : 


\section{The Birth of Kūkai as a Literary Figure: A Translation and Analysis of Shinzei's Preface to the Henjo Hokki Shōryōshū}

WILLIAM MATSUDA

\section{Introduction}

A LONG with such celebrated literati as Emperor Saga 嵯峨天皇 (786-842, r. 809-823), Ono no Minemori 小野岑守 (778-830), and Yoshimine no Yasuyo 良岑安世 (785-830), Kūkai 空海 (774-835) is often considered one of the outstanding kanshi 漢 詩 poets of the early Heian period. Indeed, even a brief glance at his poetic output amply demonstrates his vast erudition in the Chinese classics and his creative prowess. In modern times, the image of Kükai as a canonized literary figure is reinforced by the inclusion of a volume devoted to his writings in the Nihon koten bungaku taikei 日本古典文学大系 (henceforth, NKBT), a 102-volume collection of the premodern literary "classics." The addition of Kūkai's works to this anthology in 1965 was a declaration that he could be appreciated as a figure worthy of membership at the highest echelons of the Japanese literary world, not just as an esoteric theologian or the protagonist of innumerable legends. Nevertheless, modern collections of "literary classics" are deceptive because the anthologized texts are presented as timeless monoliths of uncontroversial canonicity. The presence of Kūkai's poetic oeuvre among premodern masterpieces lends the impression that the "literary" quality of his work was immediately apparent from the onset. Yet, despite the laudatory assessment that Kükai's compositions have received in later centuries, his reputation as a poet was not firmly established during his lifetime. This paper argues that Shinzei 真済 (800-861), one of Kūkai's senior disciples, was responsible for the earliest attempts at portraying Kūkai as a literary figure. Textual evidence for Shinzei's agenda is present in the preface he penned for the Henjō hokki shōryōshu 遍照発揮性霊集, ${ }^{1}$ an anthology of Kūkai's poetry and prose that Shinzei edited. An analysis of this preface suggests that Shinzei's attempts at literary canonization were intended to generate political and cultural capital for himself in the turbulent years immediately following Kūkai’s death.

\section{About the Henjō hokki shōryōshū}

Compared to Kūkai's doctrinal works, the texts collected in the Henjō hokki shōryōshū (henceforth, Shōryōshü $)^{2}$ are not widely studied by scholars either

Possible translations of this title will be discussed below.

2 A note on the transcription: while texts from the Heian period transcribe the characters 性霊集 as Seireishū, this study will follow modern conventions and transcribe the collection's title as Shōryōshū. 
in Japan or abroad. ${ }^{3}$ This is not surprising, since the Shōryōshū lacks the thematic cohesion and philosophical synthesis of his religious treatises. Nevertheless, the Shōryōshū contains many important documents: letters that Kūkai wrote to various officials while in Tang China, the epitaph he dedicated to his departed master Huiguo 恵果 (746-806), along with numerous poems, memorials, and votive documents.

David Gardiner, who has published translations of two documents from the Shōryōshū, offers the following comments:

\begin{abstract}
Although the Shōryōshū does not contain any of Kūkai's major doctrinal works, many of its texts portray esoteric Buddhist theories as refracted through the lens of actual practice, thereby revealing how Shingon Buddhism took shape in its initial stages, during his lifetime. The Shōryōshū is an important historical resource for understanding the concrete means by which Kükai propagated Shingon Buddhism. ${ }^{4}$
\end{abstract}

Indeed, since the Shōryōshū is a collection of miscellaneous documents on a variety of subjects produced over the course of Kūkai's life, it provides a variety of insights into his everyday activities in religion, politics, and literature.

The 111 pieces of prose and poetry contained in the Shōryōshu are divided into ten volumes, with each volume generally dedicated to a specific category of writing, such as poetry, epistles, epitaphs, or votive documents. Textual studies on the transmission of the Shōryōshù text show that the first seven chapters of the collection have remained intact since their original compilation by Shinzei. However, at some point during the mid-Heian period the last three volumes were lost, so in 1079 Saisen 済暹 (1025-1115), a scholar-monk at the Ninnaji 仁和寺 temple in Kyoto, visited various

3 An exception is Judith Rabinovitch and Timothy Bradstock's Dance of the Butterflies: Chinese Poetry from the Japanese Court Tradition (Ithaca, NY: Cornell University Press, 2005). They hold the Shōryōshū in high regard, stating "Kūkai's collection of largely Buddhist Chinese poetry and prose, Seireishū [Shōryōshū] remains a classic in the Chinese literary tradition of the Heian court and bears testimony to his belief in the high value of Chinese letters in imparting Buddhist doctrine." Rabinovitch and Bradstock, 20.

4 David Gardiner, "The Consecration of the Monastic Compound at Mt. Kōya," in David White, ed., Tantra in Practice (Princeton, NJ: Princeton University Press, 2000), 127. temple libraries and recompiled the missing volumes using primary source texts he located. Yamazaki Makoto has suggested that Saisen's efforts at recovering the Shōryōshū were an attempt to reassert Kūkai's prestige in the face of Tendai revivalism. ${ }^{5}$ Strictly speaking, the last three volumes are referred to as the Shōryōshū hoketsushō 性霊集補閶鈔 (Supplement to the Shōryōshū), but for the purposes of this study, the entire collection will be referred to as the Shōryōshū. While Saisen presents the entire collection as Kükai's work, modern scholarship generally agrees that the authorship of a number of the texts in the Shōryōshū hoketsushō cannot be positively attributed to Kūkai.

The documents in the Shōryōshū provide a glimpse into the multiple facets of Kükai's complex life that cannot be readily discerned solely from his doctrinal writings. They demonstrate that Kükai was not only an innovative theologian and erudite writer, but also a shrewd politician, a formidable advocate, and a passionate educator. Also, as these texts were produced by Kūkai during his actual lifetime, the Shōryōshū makes it possible to extricate Kükai from the discourse of the Kōbō Daishi legend and squarely position him within the political, social, and literary milieu of his day.

Several years before Kūkai's death in 835, Shinzei started gathering the documents that appear in the collection. In addition, Shinzei authored the preface, a key text to understanding his attempt to canonize his master and generate political capital for himself. A complete, annotated translation of the preface is presented below. ${ }^{6}$

\section{Shinzei's Preface to the Shōryōshū}

\section{西山禪念沙門眞濟撰集}

Compiled by Shinzei, Meditation Monk in the Western Mountains ${ }^{7}$

5 Yamazaki Makoto 山崎誠, “Kaidai,” 解題 in Abe Yasurō 阿部安 郎 and Yamazaki Makoto, eds., Shōryōshūchū 性霊集注 (Kyoto: Rinsen Shoten, 2007), 837.

6 Translation by William Matsuda. NKBT vol. 71 used as the source text (see note below).

7 The Western Mountains refer to the Takaosanji temple. Watanabe Shōkō 渡辺照宏 and Miyasaka Yūshō 宮坂宥勝, eds., Sangō shiiki, Shōryōshū 三教指帰, 性霊集, in Nihon koten bungaku taikei 日本古 典文学大系, vol. 71 (Tokyo: Iwanami Shoten, 1965), 150. 
余少小也頗貴先氏之風。志学之後。楽寂歴而 不屑此事。仰幽人之幽行。爰有一上人。耽大 道之大妙。号曰大遍照金剛。青襟積槐林之春 秋。絳帳富山河之英萃。遂則婳域中近智。慕 超然遠猷。出俗入真去偽得貞。

When I was young, I had deep respect for the scholarly ways of my ancestors. But after reaching the age of "aspiration to learning," I found solace in tranquility and lost interest in the Confucian teachings. Revering the profound actions of profound people, ${ }^{9}$ I immersed myself in the great mysteries of the Great Way. There is a saint named Dai Henjō Kongō. In the spring and fall of his student days he wore a blue collar ${ }^{10}$ and plucked the fruits of the forest of learning. Then, he displayed the scarlet curtain ${ }^{11}$ of a teacher and collected the flowers of the mountains and rivers. Despising the shallow wisdom of our isolated land, he yearned for the transcendent and the profound. He left the vulgar and entered the true; he departed from the false and obtained the pure.

8 The age of fifteen, as recorded in the Analects: "The Master said, 'At fifteen I set my heart on learning; at thirty I took my stand; at forty I came to be free from doubts; at fifty I understood the Decree of Heaven; at sixty my ear was attuned; at seventy I followed my heart's desire without overstepping the line'" 子曰吾十有五 而志乎學三十而立四十而不惑五十而知天命六十而耳順七十而從 心所欲不踰矩. D.C. Lau, trans., The Analects (London: Penguin Books, 1979, 62); Kanaya Osamu 金谷治, ed. Rongo 論語 (Tokyo: Iwanami Shoten, 1964), 28.

9 "Profound people" 幽人 refers to the buddhas and bodhisattvas. (Watanabe and Miyasaka, 150).

10 Blue collars as student emblems are based on a poem in the Book of Songs:

青青子衿 $\bigcirc$ you, with the blue collar,

悠悠我心 Prolonged is the anxiety of my heart.

縱我不往 Although I do not go [to you]

子寧不嗣音 Why do you not continue your messages [to me]?

Imataka Makoto 今鷹真, et al., eds., Henjō hokki shōryōshū 遍照 発揮性霊集, in Kōbō daishi Kūkai zenshū henshū iinkai 弘法大師空 海編集委員会, eds. Kōbō daishi Kūkai zenshū 弘法大師全集, vol. 6 (Tokyo: Chikuma Shobō, 1984), 152; James Legge, The She King (Hong Kong: Hong Kong University Press, 1960), 144.

11 The "scarlet curtain" 綘帳 is the scarlet silk curtain displayed by Confucian scholar and commentator Ma Rong 馬融 (79-166) when he lectured. Imataka et al., 152. According to the History of the Later Han, Ma "occupied an elevated hall. He sat before a scarlet curtain to teach his students; behind it were his female musicians. The students taught one another in order of seniority; rarely did anyone 'enter his chamber." Haun Saussy, "Classical Exegesis," in Victor H. Mair, ed., The Columbia History of Chinese Literature (New York: Columbia University Press, 2001), 912.
复瞰豁渓之美。神木霊草之区。耳目所経未嘗 不究。毎歏曰。堤葉彫落久。龍苑待何春。吾 生之愚憑誰帰源。但法有在。起予是天。天随 其願果擢求法。去延暦未銜命入唐。適見京城 青龍寺大徳恵果阿闍梨。

The beauty of the towering peaks and wide valleys and the variety of holy trees and sacred grasses tantalized his eyes and ears, and he could not help but be astounded. He frequently lamented, "It has been an eternity since the bodhi leaves fell. What spring does the dragon blossom tree await? ${ }^{12}$ As I was born foolish, whom shall I rely upon to return to the Source? Yet, surely this Dharma exists, and what shall guide me is Heaven."1 ${ }^{.13}$ The emperor, assenting to his prayer, finally selected him to be a Dharma-seeking monk. At the end of the Enryaku reign, an era now long past, he journeyed to Tang China on the emperor's orders. ${ }^{14}$ In the capital, he happened to meet the acharya Huiguo, the revered priest of the Qinglongsi temple.

即南天䇥大弁正三蔵上足弟子。代宗皇帝所師 供也。和尚始一目以喜。待己厚曰。吾待汝

久。来何遅矣。生期向関。精勤早受。則授二 部大曼茶羅法。百餘部秘蔵。上人性也。得善 聆声知意経目止口。積年之功旬時学得。

Huiguo was a senior disciple of the Indian monk Amogavajra, the Great Senior Preceptor of the Tripitaka who had served Emperor Daizong. ${ }^{15}$ Huiguo took one look at him [Kükai] and was overjoyed. Welcoming him, warmly he said, "I have waited for you for so long. Why did you come so late? My life is almost at an end. Be diligent

12 The dragon-blossom tree is supposed to blossom when the bodhisattva Maitreya appears in the world. (Watanabe and Miyasaka, 151).

13 This is an allusion to the Analects: "The Master said, 'There is no one who understands me.' Tsu-kung said, 'How is it that there is no one who understands you?' The Master said, 'I do not complain against Heaven, nor do I blame Man. In my studies, I start from below and get through to what is above. If I am understood at all, it is, perhaps, by Heaven.' 子曰莫我知也夫子貢曰何為其莫 知子也子曰不怨天不尤人下學而上達知我者其天乎. Watanabe and Miyasaka, 150; Lau, 129; Kanaya, 203. "Heaven" indicates the emperor.

14 The phrase "sent on a mission on the ruler's orders" 銜君命而使 appears in the Liji 礼記. (Book of Rites). Watanabe and Miyasaka, 150.

15 Emperor Daizong 代宗 ruled from 762-779. 
and quickly receive my teachings." Then Huiguo conferred the teachings of the dual Womb and Diamond mandalas and more than one hundred ${ }^{16}$ texts from the secret treasury. Saint Kükai's nature was such that he could understand the import of what he heard, and whatever his eye passed over was retained by his tongue. He accumulated years' worth of effort and learning in a single season.

大師亦奄然而従化。故付法云。今有日本沙門 来求聖教。以両部秘奥壇儀印契。唐梵無差悉 受於心。猶如寫瓶。吉矣汝伝燈了吾願足焉。 金剛薩捶扣大日之寂後。所謂第八折負者吾師 是也。故得伝命以唐梵之式。答恩以秘密之 実。真言加持之道日来漸。曼茶羅頂之風是時 彌布。

The Great Master Huiguo suddenly went to his death. ${ }^{17}$ That is why when Huiguo transmitted the Dharma to Dai Henjō Kongō he said, "Now, there is a monk from Japan who came to seek the sacred teachings, embodied in the secret rituals and mudras of the Womb and Diamond platforms. He has taken the pledge in both the Womb and Diamond mandala chambers. Whether in Chinese or in Sanskrit, he received the teachings in his heart; it was like pouring water from one jar into another. How fortunate that I transmitted the lamp to you! My prayers have been fulfilled." My master is the eighth in line from Vajrasatta, who sought the samadhi of Mahāvairocana. ${ }^{18}$ That is why he used both Chinese and Sanskrit rituals to fulfill his mission of transmitting the Dharma to Japan and used the treasure of esoteric teachings to display his gratitude to the emperor. The way of Shingon rituals was transmitted on that day, and abhisekha using mandala spread from that moment on.

\section{是即以我上国聖出運大化兼徹。而令印度新教}

16 According to the Goshōrai mokuroku, there were 142. Ibid.

17 化 is an abbreviation of 遷化, which refers to the death of a high priest. Ibid.

18 Vajrasatta 金剛薩捶 is considered the second patriarch of esoteric Buddhism. In the Mahāvairocana sutra, Vajrasatta resides in Mahavairocana's cosmic palace and serves as his interlocutor for his discourses on all-embracing wisdom and enlightenment. Ryuichi Abé, The Weaving of Mantra: Kükai and the Construction of Esoteric Buddhist Discourse (New York: Columbia University Press, 1999), 131-2.
授若人以安来者矣。于嗟迷方問津何得千里即 目。弟子久渇清鹿恭至下風。鐘籟相響新扣如 舊。執事年深未見其浅。誠知二気变龍雲雷成 章。信不虚言哉。和尚昔在唐日作離合贈土僧 惟上。前御史大夫泉州別駕馬総一時大才也。 覧則驚怪因送詩云。

Our Emperor Kanmu, a sage whose like appears once every thousand years, spread his vast virtue throughout the realm, making it possible for Kükai to bring peace to future generations with these new teachings from India. Ah! Lost, I ask for the way to the ford; how can I see thousands of $l i$ ahead ${ }^{19}$ I, his disciple, have long sought a world free of dust, so I reverently received his teachings. Just as a bell and flute are in perfect harmony, newly acquainted people may speak to each other as though they were old friends. Though I have served him for many years, I have yet to see anything shallow in his thought. The dual forces of yin and yang transforming into a dragon and then forming clouds that create thunder-I now know that this is not an empty saying! ${ }^{20}$ Long ago, when the master was in China, he composed a poem in the $l i$ he style and presented it to Weishang, a local monk. ${ }^{21}$ Ma Zong, the former Inspector General

19 In the Analects, Zilu (Tsu-lu) 子路 asks two men plowing a field for directions to the river crossing. Upon learning that Zilu was a disciple of Confucius, one of the men says (in derision) that Confucius should already know the way. Watanabe and Miyasaka, 152; Lau, 150; Kanaya, 253-4. Here, it seems that Shinzei has inverted the rhetorical thrust of the source text and turned it into an expression of humility.

20 Modern commentators have opposing interpretations: Shinzei is praising his ability to immediately absorb Kükai's teachings, Imataka et al., 154, or the inability of his disciples to perceive fully the profundity of his actions, Watanabe and Miyasaka, 154. The second interpretation draws on commentary to the Daode jing. Ibid.

21 Weishang was one of Huiguo's disciples, and was mentioned in the epitaph that Kūkai composed for Huiguo (refer to Chapter Two). Lihe 離合 (separating and joining) refers to a "miscellaneous" style of Chinese poetry where the component of the Chinese character (such as the radical or the remainder) used to start the first line is then used to begin the second line. Although the li he poems that Kükai and Weishang exchanged are no longer extant in any sources from the period, the Kansekishō 緘石鈔, a commentary on the Shōryōshū written by Saisen, claims to contain one of the li he poems Kükai wrote in China:

磴危人難行 Stone-paved slopes crumble, they are difficult for people to traverse

石嶮獣無登 The rocks are steep, wild beasts do not climb them 
and Vice-Governor of Quanzhou, ${ }^{22}$ was one of the great talents of his generation. He saw Kūkai's poetry and was astounded with disbelief. Therefore, he sent Kūkai the following poem:

\section{何乃萬里来 Why have you come from so far away? \\ 可非彷其才 Surely not to flaunt your talents! \\ 増学助玄機 Study even harder and aid the profound teachings! \\ 土人如子稀 People here like you are rare}

\section{其後藉甚満邦緇素仰止。詩賦往来動剰筮笥。 遂使絶域写憂殊方通心。詞翰俱美誠興東方君 子之風。故昆陵子胡伯崇歌云。}

Afterward, his fame spread ${ }^{23}$ throughout the land, and he was revered by both laymen and clergy. Poems and rhapsodies were exchanged back and forth, and before long his letterbox was filled with poetry. In this way he let out his laments in a faraway land, and gave expression to his feelings

\footnotetext{
燭暗迷前後 The torch is extinguished, there is confusion all around

蜀人不得過 People from Shu would be unable to make their way through
}

The first character in the second line 石 (stone) is the radical from the character that opens the first line 磴 (stone-paved slope).

The reverse operation is performed in the third and fourth lines: the non-radical remainder (in this case, the phonetic portion) of the first character in the third line 燭 (torch) is used to start the fourth line 蜀 (Shu, a non-Han kingdom located near present-day Chengdu, Sichuan Province), lbid., 493.

22 Shinzei lists two distinct titles for Ma Zong: former Inspector General 前御史大夫 and Vice-Governor of Quanzhou 泉州別駕. Quanzhou is part of modern-day Fujian Province. Inspector General was a fairly high position (Junior Third Rank, one step below the Ministers of State) and responsible for supervising government officials. A provincial vice-governor was classified as Fifth Rank, Lower. The Old Records of the Tang 旧唐書 and the New Records of the Tang 新唐書 both mention that Ma Zong was appointed vice-governor as a demotion, but not his former service as an Inspector General. Imataka et al., 154. Ma Zong claimed also to be the descendant of Ma Yuan 馬元 (14-49), the famed Han general who suppressed a rebellion in what is modern-day Vietnam and erected "bronze pillars" to mark the southern boundaries of the Han state. Historical veracity notwithstanding, Ma Zong also claimed to have erected bronze pillars at the same site to commemorate his great-ancestor's achievement. Liam Kelley, Beyond the Bronze Pillars: Envoy Poetry and the Sino-Vietnamese Relationship (Honolulu, HI: Association for Asian Studies and University of Hawaii Press, 2005), 7, 102.

23 The phrase 藉甚 is an abbreviated quotation of a line from the Records of the Han: 名声藉甚. Imataka et al., 154-5. in a foreign country. His diction and writing were both beautiful, and he truly adopted the style of the Eastern gentleman. ${ }^{24}$ That is why Hu Bochong of Piling ${ }^{25}$ said in his song:

説四句演昆尼 Preaching on the Four Verses and expounding on the Precepts

凡夫聴者盡帰依 All those who hear these shall take refuge

天假吾師多伎術。就中草聖最狂逸。不可得難 再見。是以啄雞奔獣之點獨留九州。涌雲迴水 之画盛变八紘。或臥煙霞而獨嚷任意腑詠。或 対天問以献納随手成章。至如慕仙詩。高山風 易起。深海水難量。又遊神泉。高台神構非人 力。池鏡泓澄含日暉。

The heavens have granted my master many skills, but none as extraordinary as his grass script. How rare-it will be difficult to see such talent again! It is for this reason that the calligraphic styles depicting the power of a rooster's beak or a charging beast have remained in the Nine Provinces of China, and brushwork like floating clouds and flowing water have spread to Japan. One day, Kūkai lay in the mist talking to himself and committed his thoughts to poetry. On another day, he presented a poem in reply to the emperor, and it was as though the writing just flowed from his hand. In a poem where he seeks the mountain sage, he wrote, "On tall peaks, the wind is easily aroused/In deep seas, water is difficult to measure."

24 The "Records of Eastern Barbarians" 東夷伝 chapter of the Records of the Later Han 後漢書 refers to a land of gentlemen across the eastern seas. Watanabe and Miyasaka, 154

$25 \mathrm{Hu}$ Bochong 胡伯崇 (dates unknown) was a poet whom Kūkai apparently encountered in China, but very little is known about him, and the specific location of Piling cannot be ascertained from Chinese gazetteers of the period. Watanabe and Miyasaka, $154,493$.

26 This is likely to be from a gatha 偈 (Chn. ji, Jpn. ge) known as the Gatha on the Admonitions of the Seven Buddhas 七仏通戒偈，a compilation of the common teachings of the historical Buddha and the six Buddhas who came before him. The "four verses" are:
諸悪莫作
衆善奉行 Commit no acts of evil
自浄其意 For the benefit of all, perform acts of good
是諸仏教 Keep one's thoughts pure These are the teachings of the Buddhas 
Also, when he visited the Shinsen'en Garden, he wrote, "The high dais is the work of the gods and not of man/The mirror-like surface of the pond is crystal clear and absorbs the sunlight."

比興争宣気質衝揚。風雅勤戒煥乎可観。夫其 詩賦哀讃之作。碑誦表書之制。所遇而作不假 草案。纔了不競把。無由再看之。弟子憂金玉 糅谿。歎蘭桂壓秋艾。侍坐而集記略得五百以 来紙。兼摭唐人贈答。稍警策雑此帙中。編成 十巻。名曰遍照発揮性霊集。其餘調分巻別 者。今之所不撰也。願吾黨好事永味師迹。俾 禅餘之憩来。時時披対此文。唯備一菴遊目。 誰稱他人沽哉。

In these verses simile and metaphor vie with each other, and instruction and odes shine throughout. ${ }^{27}$ The poems, rhapsodies, laments, and praises he composed and the monuments, prayers, petitions, and calligraphy he produced were created on the spot without benefit of a draft. If you did not seize a text as soon as he finished it, you would never see it again. I, his disciple Shinzei, worry that the gold and jade will mingle with stones in the riverbed, and lament that the orchids and cassia will be overrun by the autumn mugwort. Serving at his side, I have collected and transcribed his writings, accumulating over five hundred pieces of paper. In addition, I have included his correspondence with people of Tang as outstanding examples of poetry and prose. This collection of ten volumes I have named the Henjō hokki shōryōshū. Extraneous texts that fall outside the categories presented in these volumes have been excluded for the time being. It is my wish that Kükai's disciples savor his writings for years to come, and that they occasionally open and read these volumes as respite from their meditation. Mere amusement for the eye while alone in one's hut-who would think of peddling them to others? ${ }^{28}$

27 Shinzei references four of the six modes of expression found in the Book of Songs: bi 比 (simile), xing 興 (metaphor), feng 風 (instruction) and ya 雅 (odes). The remaining two are fu 賦 (description) and song 頌 (hymn). Imataka et al., 155; Victor $\mathrm{H}$. Mair, "Introduction: The Origins and Impact of Literati Culture," in Victor H. Mair, ed., The Columbia History of Chinese Literature (New York: Columbia University Press, 2000), 5.

28 This is a reference to the Analects: "Tsu-kung said, 'If you had a beautiful piece of jade here, would you put it away safely in a box

\section{Situating the Preface}

The first half of the preface provides a summary of the key elements common to hagiographic narratives on Kükai: his first encounter with Huiguo, how this encounter was predicted by Huiguo, and how transmitting the esoteric teachings to Kükai was as simple as "pouring water from one jar into another." Kūkai's facility in Chinese and Sanskrit-staples in any account that mentions Kūkai's sojourn in Tang China-are also mentioned.

Once the requisite details establishing Kūkai's background and lineage are provided, Shinzei describes Kūkai's literary accomplishments. He does not attempt to situate Kūkai's literary output into an overtly Confucian "statescraftism" or esoteric Buddhist discursive frame; rather, he presents Kūkai as a literary talent in his own right. By mentioning Kūkai's encounters with literati-bureaucrats such as Ma Zong 馬総 (?-823), who declares Kūkai to possess a talent rarely found even in China, Shinzei establishes Kūkai as a literary figure on a par with the Chinese, something that very few Japanese literati (even those who were prolific poets in Chinese) could claim. However, this strategy should not be interpreted as an attempt to marginalize kanshi composed by other Japanese as inferior. Rather, Kūkai's experiences in China are used to compensate for his lack of proper credentials, especially the completion of a course of study at the State College. In other words, since Kūkai was not in a privileged position as a canonical writer, "China" is evoked to provide an alternative source of legitimacy, not to challenge the quality of Japanese kanshi. Finally, Shinzei cites specific poems composed by Kūkai and presents them as examples of "simile" 比 (Ch. bi) and “metaphor" 興 (Ch. xiao), demonstrating Kūkai’s mastery of poetic forms found in canonical sources such as The Book of Songs.

Shinzei also explicitly states another major objective in compiling the Shōryōshū: collecting and preserving Kükai's best literary works for the benefit of his disciples and for future generations. He also presents the potential for Kūkai's writings to serve as a diversion by

or would you try to sell it for a good price?' The Master said, 'Of course I would sell it. Of course I would sell it. All I am waiting for is the right offer'" 子貢曰有美玉於斯馧賣而藏諸求善賈而沽諸子 曰沽之哉沽之哉我待賈者也. Imataka et al., 156; Lau，98; Kanaya， 122. 
suggesting that the monks read them when taking a break from meditating. Finally, Shinzei hints at sharing Kükai's writings with a wider readership when he says "Mere amusement for the eye while alone in one's hutwho would think of peddling them to others?”唯備一 菴遊目誰稱他人沽哉.

The title of the collection, Henjō hokki shōryōshū, reveals a great deal about Shinzei's motives. While Kūkai saw himself as a religious and philosophical pioneer, and part-time statesman, Shinzei wanted to use the Shōryōshū to establish Kūkai as a literary figure. The title itself is infused with an amalgam of continental literary and philosophical aesthetics. Henjō 遍照 (shines throughout the world, i.e., Vairocana), was often used in part of Kūkai's Buddhist name Henjō Kōngō 遍照金 剛 (the adamantine that shines throughout the world). The expression hokki 発揮 is taken directly from a line in the Yijing 易経 (Book of Changes) that states, “The six lines, as explained (by the Duke of Kau [Zhou]), bring forth and display (its meaning), and everything about it is (thus) indirectly exhibited” 六爻発揮旁通情也. ${ }^{29}$ In other words, this phrase refers to the manifestation of latent abilities. Shōryō 性霊 literally means "the spirit of the essence," in this case, the "essence" of Kūkai's writings. Shinzei appropriated the concept of shōryō from a line in the Wenzhang 文章 (Essay on Literature) section of the Yanshi jiaxun 顔氏家訓 (Family Instructions for the Yen [Yan] Clan) by Yan Zhitui 顔之推 (531-591). ${ }^{30}$ The Yanshi jiaxun was composed during the turbulence of the late Northern and Southern Dynasties period (420-589), and its author rebuked the decadent tendencies of southern literature, as opposed to the rel-

29 James Legge, The I Ching, in Max F. Muller, ed., The Sacred Books of the East, vol. 16 (New York: Dover Publications, 1963), 415.

30 Watanabe and Miyasaka, 36. Yan Zhitui was reared in the Confucian tradition, but was also a Buddhist with a keen sense of politics. The Family Instructions for the Yen Clan is a valuable document since it provides a detailed look into aristocratic life of the period through its admonitions on a vast array of topics, such as familial relations, proper study habits, the reconciliation of theory and practice, self-sufficiency, as well as the literary arts. This collection is also considered the prototype for the jiaxun 家 訓 (family instructions) genre of writing. As a devout Buddhist, Yan vigorously defended the Buddhist faith against its critics. In addition to his writings defending the tenets of Buddhism, he compiled the Yuanhunzhi 冤魂志 (Accounts of Ghosts with Grievances), a collection of tales of karmic retribution. Helwig Schmidt-Glintzer and Victor H. Mair, "Buddhist Literature," in Victor H. Mair, ed., The Columbia History of Chinese Literature (New York: Columbia University Press, 2001), 171. ative austerity of northern culture. ${ }^{31}$ Specifically, the line Shinzei quoted reads, "I have often thought, on the basis of accumulated (experience), a body of essays exhibits the writer's interests, develops his nature, and makes him proud and negligent of control as well as determined and aggressive” 原其所積文章標挙興会 発引性霊使人矜伐故忽於持操果於進取. ${ }^{32}$ Although somewhat cumbersome, perhaps the most accurate translation of the title would be "Collection of Works that Reveal the Hidden Literary Talents of the One Who Illuminates the World." ${ }^{33}$

Yet, no anthology is a transparent enterprise. While a surface reading of Shinzei's motives suggests that he is merely attempting to preserve exemplars of his master's writing for posterity, the political milieu in which he operated cannot be ignored. Japanese scholarship generally affirms Shinzei's stance and views the anthology as a literary monument to his master. ${ }^{34}$ After Kūkai's death, rivalries among Shingon-affiliated temples, particularly Tōji and Kōyasan, meant that there was no central temple, or unified voice, for the fledgling Shingon

31 Dore J. Levy, "Literary Theory and Criticism," in Victor H. Mair, ed., The Columbia History of Chinese Literature (New York: Columbia University Press, 2001), 929-930.

32 Watanabe and Miyasaka, 36; Teng Ssu-yu, trans., Family Instruction for the Yen Clan (Leiden, The Netherlands: E.J. Brill, 1968), 90.

33 Other translations of the title include Collected Inspirations (Donald Keene), The Spirit and Mind Collection: The Revelations of Priest Henjō [Kūkai] (Rabinovitch and Bradstock), and Henjō's Collection for Giving Free Rein to the Spirit (Emanuel Pastreich). Donald Keene, Seeds in the Heart: Japanese Literature from the Earliest Times to the Late Sixteenth Century (New York: Henry Holt, 1993), 187; Rabinovitch and Bradstock, 99; Emanuel Pasterich, "The Reception of Chinese Literature in Japan," 1084.

34 Perhaps this is not such a surprise, considering that the major scholarly treatments of the Shöryōshü have been by scholars with sectarian affiliations. One of earliest attempts to provide a modern interpretation of the Shōryōshū is Sakata Kōzen's Shōryōshū kōgi 性霊集講義, published in 1942. Sakata was a professor at Kōyasan University, and the volume is a compilation of his lectures on the collection. The work itself is impressive: it presents each text in the Shōryōshū line by line, with phonetic glosses, explanations of difficult characters, a summary in modern Japanese, and a few interpretative comments. However, he provides no background information aside from what Shinzei presents in his preface, which he appears to accept uncritically. The liberal use of honorifics to refer to Kūkai and describe his actions reveals the author's sectarian bias. Sakata Kōzen 坂田光全, Shōryōshū kōgi 性 霊集講義 (Wakayama, Japan: Kōyasan Jihōsha, 1942). Watanabe and Miyasaka, the co-editors of the NKBT edition used as the primary source for this study, provide much more historical detail regarding Shinzei's life, but do not entertain the possibility of political motivations. 
school..$^{35}$ While there appeared to be no direct animosity among his disciples, differing political loyalties inevitably put them at odds.$^{36}$ One such example is Shinzei's acceptance of a request from Emperor Montoku 文徳 天皇 $(827-858$, r. $850-858)$ in 850 to perform prayers so that his son, Prince Koretaka 惟喬親王 (844-897), could ascend to the throne. ${ }^{37}$ Koretaka's mother was Ki no Seishi 紀静子 (?-866), the daughter of Ki no Natora 紀名虎 (?-847), so Shinzei was a blood relative of the prince ${ }^{38}$ However, the ascent was opposed by the Minister of the Right, Fujiwara no Yoshifusa 藤原良房 (804-872), whose daughter Meishi 明子 (829-900) was a consort to Montoku and mother of Prince Korehito 惟仁親王 (850-881). Yoshifusa enlisted the services of Shinga 真雅 (801-879), another disciple of Kūkai, who established the Shingon-in at the Tödaiji temple, to perform similar prayer rituals on behalf of Korehito. Thus, Shingon priests representing two different temples were used as pawns in a proxy struggle between the Ki and the Fujiwara, with the latter emerging victorious. ${ }^{39}$ After Montoku's abdication, Korehito assumed the throne as Emperor Seiwa 清和天皇 (r. 858-876), allowing Yoshifusa to consolidate his power base.

Therefore, Shinzei's compilation of the Shōryōshī may be interpreted as an attempt to acquire political and cultural capital by monopolizing Kūkai’s literary legacy. His origins in the highly erudite Ki clan made him well suited to the task, and the preface to the Shōryōsh $\bar{u}$ amply demonstrates Shinzei's facility in literary Chinese and his knowledge of continental source materials. His acknowledgment of the existence of texts excluded from the Shōryōshi and his reference to "over five hundred pieces of paper" demonstrate a deliberate agenda regarding the collection's editorial policy. Shinzei is declaring that he is in possession of Kükai's writings and will determine which ones are published. Also, his concern that "the gold and jade will mingle with the stones in the riverbed" and lament that "the orchids and cassia

35 Stanley Weinstein, "Aristocratic Buddhism," in Donald H. Shively and William H. McCullough, eds., The Cambridge History of Japan, vol. 2 (Cambridge: Cambridge University Press, 1999), 498.

36 Ibid

37 Ibid.

38 Sakaue Yasutoshi 坂上康俊, Ritsuryō kokka no tenkan to "Nihon" 律令国家の転換と「日本」(Tokyo: Kōdansha, 2001), 216.

39 A somewhat corrupted version of this event is recreated in Chapter Eight of The Tale of the Heike. Helen Craig McCullough, trans., The Tale of the Heike (Stanford, CA: Stanford University Press, 1988), 260-1. will be overrun by the autumn mugwort" suggests anxiety that his rivals might attempt to publish their own Kūkai anthologies and establish competing interpretive traditions. Shinzei reassures his readers that he had exclusive access to Kükai and his writings, claiming that he served "at his side" as his amanuensis.

\section{Conclusion}

Shinzei's preface to the Shöryōshù was a monument to Kükai's literary talents and an embodiment of his wish to preserve the best examples of Kükai's writings for future generations. Situating the Shōryōshu within the political milieu of its day reveals another agenda: creating political and cultural capital for Shinzei after Kūkai's death. A lack of unity in the newly formed Shingon "school" inevitably put Kükai's disciples at odds, so Shinzei drew on his background as a member of the erudite Ki clan to recast his departed master as a literary figure. In the preface, he established himself as an authority on Kūkai's writings by highlighting his unparalleled access and editorial powers. The interpretation and transmission of Kükai's legacy in the years following his death are often understood within the framework of hagiographies based on the Kōbō Daishi legend. In contrast, the Shōryōsh $\bar{u}$ and its preface present an opposing tradition, where Kūkai is venerated as a real person navigating the literary and political milieu of his day.

\section{Bibliography}

Abé, Ryūichi. The Weaving of Mantra: Kūkai and the Construction of Esoteric Buddhist Discourse. New York: Columbia University Press, 1999.

Gardiner, David L. "The Consecration of the Monastic Compound at Mt. Kōya." In Tantra in Practice, edited by David White, 119-30. Princeton NJ: Princeton University Press, 2000.

Imataka Makoto 今鷹真, Kanaoka Shūyū 金岡秀友, Kanaoka Shōkō 金岡照光, and Makio Ryōkai 牧尾良海, eds. “Henjō hokki shōryōshū” 遍照発揮性霊集. In Kōbō daishi Kūkai zenshū henshū iinkai 弘法大師空海全集委 員会, eds. Kōbō daishi kūkai zenshū 弘法大師空海全集, vol. 6. Tokyo: Chikuma Shobō, 1984.

Kanaya Osamu 金谷治, ed. Rongo 論語. Tokyo: Iwanami Shoten, 1964. 
Kelley, Liam. Beyond The Bronze Pillars: Envoy Poetry and the Sino-Vietnamese Relationship. Honolulu, HI: Association for Asian Studies and University of Hawaii Press, 2005.

Lau, D. C., trans. The Analects. London: Penguin Books, 1979.

Legge, James. “The I Ching.” In Max F. Muller, ed., The Sacred Books of the East, vol. 16. New York: Dover Publications, 1963.

- The She King. Hong Kong: Hong Kong University Press, 1960.

Levy, Dore J. "Literary Theory and Criticism." In Victor H. Mair, ed., The Columbia History of Chinese Literature, New York: Columbia University Press, 2001, 916-39.

Mair, Victor H. "Introduction: The Origins and Impact of Literati Culture." In The Columbia History of Chinese Literature, edited by Victor H. Mair, 1-15. New York: Columbia University Press.

McCullough, Helen Craig, trans. The Tale of the Heike. Stanford, CA: Stanford University Press, 1988.

Rabinovitch, Judith, and Timothy Bradstock. Dance of the Butterflies: Chinese Poetry from the Japanese Court Tradition. Ithaca, NY: Cornell University Press, 2005.

Sakata Kōzen 坂田光全. Shōryōshū kōgi 性霊集講義. Wakayama: Kōyasan Jihōsha, 1942.

Sakaue Yasutoshi 坂上康俊. Ritsuryō kokka no tenkan to “Nihon”律令国家の転換と「日本」. Tokyo: Kōdansha, 2001.

Saussy, Haun. "Classical Exegesis." In The Columbia History of Chinese Literature, edited by Victor H. Mair, 909-15. New York: Columbia University Press, 2001.

Schmidt-Glintzer, Helwig, and Victor H. Mair. "Buddhist Literature." In The Columbia History of Chinese Literature, edited by Victor H. Mair, 160-72. New York: Columbia University Press, 2001.

Teng Ssu-yu, trans. Family Instruction for the Yen Clan. Leiden, The Netherlands: E.J. Brill, 1968.

Watanabe Shōkō 渡辺照宏 and Miyasaka Yūshō 宮坂宥勝, eds. Sangō shiiki, Seireishu. Nihon koten bungaku taikei 71. Tokyo: Iwanami shoten, 1965.

Shōryōshū 三教指帰, 性霊集. In Nihon koten bungaku taikei 日本古典文学大系, v. 71. Tokyo: Iwanami Shoten, 1965.

Weinstein, Stanley. "Aristocratic Buddhism." In The Cambridge History of Japan, vol 2., edited by Donald $\mathrm{H}$. Shively and William H. McCullough, 449-516. Cambridge: Cambridge University Press, 1999.

Yamazaki Makoto 山崎誠. “Kaidai” 解題. In Shōryōshūchū 性霊集注, edited by Abe Yasurō 阿部安郎 and Yamazaki Makoto, 837-88. Kyoto: Rinsen Shoten, 2007. 